ALEKSANDER GRZELAK'

\title{
Accumulation of assets in farms covered by the FADN farm accountancy system in Poland - the economic and eco- efficiency context
}

Prof. Aleksander Grzelak, Poznań University of Economics and Business, Faculty of Economics,

Poland,

ORCID: 0000-0002-4290-4740.

\section{Introduction}

The accumulation of assets is a determinant of development processes in agriculture. It refers to putting aside (accumulating) the generated income in order to ensure continuity of the production process, and above all, to finance investments. Accumulation may be achieved through different channels: the income one, the credit and institutional one, and the one related to an above-average increase in the prices of land resulting from the capitalisation of subsidies, among others. The latter case refers to an increase in the value of the resource exceeding the average level of inflation (the price index of products purchased by farmers), as well as the longterm rates of return on alternative low-risk capital investments. In consequence, part of the accumulation in agriculture - from the perspective of change in equity - comes from an increase in the price of agricultural land. Paradoxically, this source of generating accumulation may limit the development of

1 The paper was financed under the funds of the National Science Centre in Poland (Grant no. 2018/29/B/HS4/01844). 
agriculture due to the fact that increased prices of land and lease fees hinder the transformations of the area structure. The first two of the channels listed above are the most desirable from the point of view of the development of agriculture. This is due to the fact that these channels trigger a sequence of actions enabling the development of farms. The point is that in this case, accumulation is usually related to an increase in the productivity of production factors, the capital-labour ratio. On the other hand, an increase in the productivity of production factors is a source of generating accumulation, hence we are dealing with the mechanism of feedback here.

Accumulation achieved through agricultural income is maintained by direct payments (mainly area payments). They make it possible to stabilise the changeability of the profitability of agricultural production, mitigate risk, generate savings, and increase investments. On the other hand, however, as mentioned before, they may capitalise in the value of agricultural land. Due to the implementation by the farmer and his family, forming the household, also the utility maximisation function (as a consumer) only satisfying the consumption needs allows creating savings that can be allocated to investments, constituting the basis for an increase in the value of the assets. Therefore, savings - which are the basis for investment and generation of accumulation - can only be made in a situation in which the income is higher than the consumer needs of the farmer's family. A reverse relationship is also possible. An increase in the value of capital has a positive influence on investments (by generating higher income), whereas investments positively impact savings (Behrman et al. 1995).

In literature on the subject, many studies on accumulation refer to the capitalisation of agricultural support (Swinnen and Vranken, 2009; Góral and Kulawik, 2015). They show that direct payments under the CAP are deposited in the rates of land lease, the price of land, and other fixed assets. An interesting discussion on accumulation was included in the study by (Barham et al. 2000). It draws attention to the fact that the accumulation of capital in agriculture is a function of the past (primary accumulation) and in consequence, smaller farms with a lower level of assets have difficulty "catching up" with the economically stronger ones. At the same time, due to the evolution of the EU's CAP towards greater valorisation of the environmental dimension of functioning of farms, attention was paid to the context of public goods and of eco-efficiency (in the sense of the relation of output value to environmental input) (Picazo-Tadeo et al., 2011; Bonfiglio et al. 2017). In the second of mentioned issues it is increasingly raised in the literature (Gadanakis et al. 2015, Van Passel et al. 2006; Czyżewski et al 2018). It is about recognizing what changes in eco-efficiency are accompanied

\footnotetext{
Accumulation of assets in farms covered by the FADN farm accountancy system in Poland - the economic and eco-efficiency 
by a higher accumulation. Is the higher of transformation of environmental input into output effects related to the improvement of accumulation?

The primary objective of the article is to identify the accumulation processes in farms in Poland based on the economic size as well as the context of ecoefficiency (from the perspective of Environmental Sustainable Value). At the same time, the following research questions were formulated:

- what are the differences in the accumulation processes in the group of farms under study?

- is higher accumulation accompanied by higher eco-efficiency of farms?

- what is the significance of subsidies for the shaping of accumulation?

\section{Research methodology}

The article uses data from farms keeping farm accounts in compliance with the principles of the FADN system. The data refers to the arithmetic means of an average farm from a specific group of farms. The temporal scope of the analyses includes the years 2004-2016. Research focuses on groups of farms due to their economic size (see footnote 2). This made possible to compare the studied phenomena with the context of the scale of production.

The accumulation was considered through the prism of change in the value of the farms' equity (SE506). It therefore includes changes in the value of unencumbered farm assets (free from liens and claims). Hence, the accumulation of assets in the article means a change (usually an increase) in the value of components of assets (most often land and other fixed assets, and less frequently working capital), which are financed with own capital of the farm, or result from capitalization of subsidies or speculation on the agricultural land market. The values of the analysed parameters were presented in PLN after realignment. Data referring to the amount of subsidies, including subsidies for public goods, was also used. These include agri-environmental payments, payments on account of set aside, support for less-favoured areas (LFA), and other payments for the development of rural areas (Czyżewski, 2017). It allowed to evaluate the importance of subsidies to public goods in total subsidies and to determine the nature of farm development also in comparison with accumulation processes. On account of the considerable significance of changes in land prices in the shaping of accumulation, relevant estimates of this element of accumulation were made using changes in land prices per 1 ha of own land. Accumulation was analysed mainly from the perspective of the accumulation rate index (accumulation/income), taking into consideration the 
economic size of farms $(\mathrm{ES6})^{2}$. This index reflects the relationship between accumulation and income in the context of the generation of accumulation from income.

The article also addresses the environmental context from the point of view of the return to cost ratio (RTC) using the Sustainable Value (SV) concept. And the previously mentioned payments for public goods. The SV method is a value-oriented one (Liesen et al. 2009). It enables synthetic assessment of the farms' contribution to farming sustainability, taking into account the efficiency resulting from the use of environmental resources by comparison with their opportunity cost benchmark (Figge and Hahn, 2005; Illge et al. 2008; Van Passel et al. 2007). Relative measurement of the so-called eco-efficiency is used here (1). The point is to answer the question of how effectively the environmental inputs are transformed into output value by the farm (group of farms)?

The following variables characterising the environmental dimension were used: share of cereals in the

$$
\mathrm{ESV}_{\mathrm{i}=} \frac{1}{m} \sum_{j=1}^{m} r_{i j}\left(\frac{y_{i j}}{r_{i j}}-\frac{y b_{i j}}{r b_{i j}}\right)
$$

where: ESVi is the sustainable value afferent to a farm with economic size $\mathrm{i}$; rij and rbij represent the quantity of the type $\mathrm{j}$ resource and the economic size $i$ of the analysed farm, i.e. of the farm considered as the reference system; $y_{i j}$ and $y b_{i j}$ are the return of resources of the analysed and benchmark farm; $i=1 . . n$ is the economic size and $j=1 . . . m$ is the type of the analysed resource.

crop structure, forest cover index for the acreage of land used, stock density (LU/ha), purchase value of fodder for animals, purchase value of fertilisers and plant protection products, energy consumption. This selection is a result of previous studies (Latruffe et al. 2004; Illge et al. 2008; Van Passel et al. 2007). I used the total output as the indicator of output. The benchmark against which we perform the sustainability performance assessment in individual economic size groups is the average value for the entire population of farms under study in the given time bracket.

2 The economic size of farms is expressed through the value of the farms' standard output (in EUR thousand): ES1 - very small farms with the annual output value of 2-8; ES2 - small 8-25; ES3 medium-small 25-50; ES4 - medium-large 50-100; ES5 - large 100-500; ES6 - very large >500.

Accumulation of assets in farms covered by the FADN farm accountancy system in Poland - the economic and eco-efficiency 
Due to the fact that the ESV is expressed in pecuniary values and depends on the absolute size of farms, it is difficult to make direct comparisons between farms with different scales of production. This is why ESV was standardised and the return to cost ratio (RTCi) (Figge and Hahn, 2005) (2), which shows the relative contribution of various types of farms to the sustainable performance compared to the benchmark, was estimated:

$$
\mathrm{RTC}_{\mathrm{i}}=\frac{y_{i}}{y_{i}-E S V_{i}}
$$

where $y_{\mathrm{i}}$ represents the created value; ESVi - environmental sustainable value of a farm with the economic size class $i$.

Values above 1 can be perceived as a share of the "clean" output with reference to the benchmark unit, while the score below 1 shows an output required to catch up with the benchmark. This means that a farm (group of farms) achieving RTC level above 1 uses its resources more efficiently than the benchmark (Burja and Burja, 2016).

\section{Research results and discussion}

The primary causative factor in the shaping of accumulation rate is agricultural income (Zegar, 2003). In the group under study, negative accumulation rate for all farms was only recorded in 2005 and 2015-2016, whereas in the remaining years, it was positive (Table 1). Even if the year 2004 - which was an exogenous shock due to the integration process was to be excluded, the average accumulation rate would remain at the level of about $20 \%$. This means that on average, 1 PLN of agricultural income generated an increase in equity at the level of 0.20 PLN. A particularly high accumulation rate could be observed in the period of favourable business outlook in agriculture, i.e. in the years 2004, 2007, and 2011. The occurrence of a positive accumulation rate in the years 2008-2009 may be a positive surprise, as in that period, considerable deterioration in the conditions for the functioning of agriculture, including a decrease in income, occurred. It may be assumed that in this case, inertia in market adjustments of farms played its part and accumulation was shaped under the influence of investments and the advantageous income situation of 2007. 
Accumulation is usually preceded by investments, which are deposited in the resources. Feedback occurs as well, and so an increase in the value of resources also contributes to an increase in income, and at a further stage - an increase in investments (Grzelak, 2014). It is difficult to draw definite conclusions regarding the tendencies in the shaping of the accumulation rate, although in the years 2004-2016, there was a downward trend, though not a clear one. This would also mean a decrease in the accumulation effort of agricultural producers.

There is a considerable diversification in the accumulation rate depending on the economic size of farms (table 1). In the period under study, a negative value was recorded only in the group of farms of the smallest economic size (ES1). It was positive in all the other groups. The accumulation effort of farms increased with their size, with a particularly high increase recorded starting with the ES4 group. The tendencies recorded should not come as a surprise due to the fact that a larger scale of production makes it possible to generate a higher income, also per capita, and thus a higher surplus after satisfying the consumer needs of the farming family. It is worth noting the polarisation among farm groups in terms of the accumulation rate (Table 1). Farms from the ES1-2 groups increasingly stand out against the remaining farm groups, in a negative way. Perhaps the relationships between income and assets moved into the next development stage, at which production concentration processes are of greater significance; on the other hand, agricultural producers in smaller farms are less and less motivated to invest and develop their agricultural business.

Table 1. Accumulation rate (accumulation/income; in \%) in farms covered by the FADN farm accountancy system in Poland based on the economic size (ES) of farms in the years 2004-2016

\begin{tabular}{c|c|c|c|c|c|c|c|c}
\hline Years & ES1 & ES2 & ES3 & ES4 & ES5 & ES6 & Total & Total-b* \\
\hline 2004 & 35.36 & 228.02 & 53.46 & 57.91 & 60.55 & 45.83 & 111.51 & - \\
\hline 2005 & -105.78 & -50.26 & -18.03 & -9.39 & 5.39 & -22.30 & -36.37 & -34.73 \\
\hline 2006 & -1.06 & 30.81 & 42.41 & 49.49 & 53.97 & 35.38 & 33.25 & 42.46 \\
\hline 2007 & 59.48 & 59.47 & 66.09 & 66.76 & 58.83 & 69.90 & 62.13 & 83.22 \\
\hline 2008 & -1.03 & 15.34 & 31.16 & 32.06 & 91.24 & 148.36 & 31.74 & 26.07 \\
\hline 2009 & -7.36 & 5.71 & 45.06 & 74.09 & 58.20 & 45.10 & 36.87 & 28.99 \\
\hline 2010 & -2.67 & 3.66 & 21.84 & 35.78 & 35.05 & 66.42 & 20.90 & 32.38 \\
\hline$-\cdot-\cdot-\cdot$
\end{tabular}




\begin{tabular}{c|c|c|c|c|c|c|c|c}
2011 & -1.52 & 44.32 & 53.86 & 62.83 & 60.56 & 56.77 & 47.29 & 51.56 \\
\hline 2012 & -7.24 & 9.60 & 32.08 & 46.92 & 51.93 & 64.42 & 31.84 & 31.8 \\
\hline 2013 & -36.73 & 1.10 & 21.93 & 40.45 & 35.15 & 31.92 & 18.52 & 16.81 \\
\hline 2014 & -59.83 & -17.89 & 6.81 & 30.31 & 27.17 & 75.31 & 8.35 & 7.37 \\
\hline 2015 & -122.94 & -26.24 & -14.73 & -2.78 & 14.02 & 11.25 & -15.71 & -14.09 \\
\hline 2016 & -79.81 & -26.58 & 6.81 & 15.78 & 18.09 & 24.53 & -3.73 & -3.67 \\
\hline Average & -25.47 & 21.31 & 26.83 & 38.48 & 43.86 & 50.22 & 26.66 & 22.35 \\
\hline
\end{tabular}

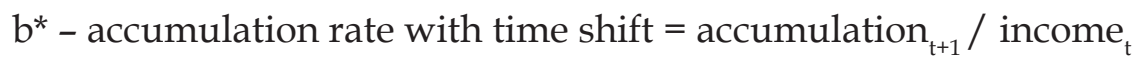

\section{Source: authors' calculations based on the FADN data} http://europa.eu.int/comm/agriculture/rica/dwh

On account of considerable differences in the accumulation rate, at the next stage of research, an attempt was made at assessing the characteristics of these processes, including those regarding the environmental context (table 2). Higher accumulation rate was accompanied by higher profitability of fixed assets, which should not come as a surprise. However, with reference to the acreage of agricultural land (AL), these relationships are more complex. The highest accumulation value per 1 ha was recorded in the group of larger, but not the largest farms (ES5). This was a result of the way agricultural income was shaped. The largest farms have more opportunities for the extensification of production and this is why they do not achieve the highest accumulation per 1 ha. The accumulation of farm assets was achieved mainly through subsidies. In the period under study, their share in the accumulation value came close to $100 \%$ only for the ES5 group of farms, in others groups was higher.

Table 2. Selected characteristics regarding accumulation in farms covered by the FADN farm accountancy system in Poland based on the economic size (ES) of farms (average for the years 2004-2016)

\begin{tabular}{c|c|c|c|c|c|c|c}
\hline Detailed division & ES1 & ES2 & ES3 & ES4 & ES5 & ES6 & Total \\
\hline $\begin{array}{c}\text { Share of subs. for pub- } \\
\text { lic goods in all subs. } \\
(\%)\end{array}$ & 25.6 & 20.0 & 15.8 & 13.9 & 11.1 & 5.0 & 17.6 \\
\hline
\end{tabular}




\begin{tabular}{c|c|c|c|c|c|c|c}
\hline $\begin{array}{c}\text { Income/fixed asset } \\
\text { value (PLN) }\end{array}$ & 3.6 & 4.9 & 6.5 & 7.4 & 9.1 & 9.8 & 5.8 \\
\hline $\begin{array}{c}\text { Accumulation/1ha } \\
\text { (PLN) }\end{array}$ & -159.1 & 373.9 & 528.5 & 794.8 & 900.1 & 393.7 & 426.8 \\
\hline $\begin{array}{c}\text { Share of subs. in in- } \\
\text { come (\%) }\end{array}$ & 104.3 & 78.0 & 57.1 & 50.5 & 45.3 & 98.7 & 69.2 \\
\hline $\begin{array}{c}\text { Share of subs. in accu- } \\
\text { mulation (\%) }\end{array}$ & -682.9 & 277.1 & 189.1 & 124.7 & 101.2 & 205.7 & 239.1 \\
\hline \begin{tabular}{c} 
Accumulation (in PLN) \\
\hline $\begin{array}{c}\text { Accumulation-subsi- } \\
\text { dies (in PLN) }\end{array}$
\end{tabular} & -1232.2 & 5217.2 & 14079.4 & 35907.0 & 90582.0 & 239337.9 & 7775.7 \\
\hline $\begin{array}{c}\text { Accumulation result- } \\
\text { ing from changes in } \\
\text { land prices (in PLN) }\end{array}$ & 2321.5 & 6129.2 & 13075.0 & 16600.5 & 28323.3 & 41994.5 & 3166.7 \\
\hline $\begin{array}{c}\text { Accumulation-accum. } \\
\text { resulting from change } \\
\text { in land prices (in PLN) }\end{array}$ & -3553.7 & -912.1 & 1004.4 & 19306.5 & 62258.8 & 197343.5 & 4609.1 \\
\hline $\begin{array}{c}\text { Pure accumulation* (in } \\
\text { PLN) }\end{array}$ & -11 & -15369.4 & -25624.2 & -25480.5 & -29373.2 & -2923.5 & -14904.3 \\
\hline \begin{tabular}{c} 
RTC (cf. 2) \\
\hline
\end{tabular} & 0.6 & 0.9 & 1.1 & 1.2 & 1.3 & 1.2 & 1.0 \\
\hline
\end{tabular}

* Pure accumulation $=$ accumulation - subsidies - accumulation resulting from changes in land prices

Source: authors' calculations based on the FADN data http://europa.eu.int/comm/agriculture/rica/dwh

Additionally, if we excluded the value associated with the increase in land prices from the accumulation, it turns out that we would be dealing with a negative value in each group of farms. To a considerable extent, this accumulation channel is related to the capitalisation of subsidies in the value of agricultural land. Research confirms that the degree of capitalisation of subsidies is substantial. In the new member states of the EU covered by the Single Area Payment Scheme (SAPS), the capitalisation rate was at a level of $19 \%$ (Ciaian and Kancs, 2012) or 15-32\% according to the estimations of Van Herck and Vranken (2013). In the case of smaller farms (ES1-3), the value of accumulation resulting from changes in land prices was higher than 
accumulation in general (Table 2). In the case of the smallest farms (ES1), this was insufficient to increase equity in real terms, even with the subsidies included. This is a result of small land resources.

The above characteristics indicate considerable significance of exogenous factors (support for agriculture, functioning of the land market) in the shaping of both accumulation and income. This might be confirmed by the results of research involving farms from 15 developing countries from different continents (Winters et al. 2009). The authors conclude that both the accumulation of assets in farms and income are the result of the state's intervention policy. From the perspective of the share of subsidies for public goods in all subsidies in smaller farms (ES12), a model of support which could be described as sustainable (payments for public goods constituted more than $20 \%$ of the subsidies) was implemented. At the same time, the share of support associated with investments did not exceed $3 \%$ of the entire support there. In the farms from the ES5-6 groups, in turn, payments for the provision of public goods did not exceed $13 \%$. So a relatively high share of subsidies for public goods was accompanied by a relatively low level and rate of accumulation. These farms are rewarded in this manner for the various functions they serve in rural areas, including the maintenance of their viability. Economic functions, including those related to accumulation, are less important there.

A slightly different approach to the issue of environmental aspects of the functioning of farms can be observed in the interpretation of the RTC ratio referring to the standardised ESV (cf. research methodology). We can see that its values among the individual economic size groups of farms were similar to those seen in the case of accumulation per 1 ha. This is also confirmed by the high correlation coefficient between ESV and the level of accumulation: 0.88 and the rather clear one between RTC and the accumulation rate: 0.6. The highest value of the standardised environmental sustainable value index was recorded for ES5 farms. This means that in this group of farms, the transformation (consumption) of environmental inputs into output (production value) was the most efficient compared to the opportunity cost determined in this case by the average of all the farms within the field of observation of the FADN farm accountancy system in Poland for the given year. The least efficient transformation could be observed in the smallest farms, i.e. the ES1 and ES2 groups. These results may indicate that smaller farms have growth reserves in terms of eco-efficiency. On the other hand, however, a barrier in their use is the relatively low resources of production factors and the scale of production, which may be the reason that in some cases, there are possibilities 
for decreasing environmental pressure at the given level of output. At the same time, research (Burja and Burja, 2016) carried out on farms in Romania indicates that smaller farms there (below EUR 50000 of standard output value) are more efficient from the perspective of ESV than the other farm groups. In particular, farms with standard output value of EUR 8 000-25 000 (ES2) in Romania have been identified as viable economic systems. A study by (Gadanakis et al. 2015), in turn, points out that based on the results of farms from the East Anglian River Basin Catchment (UK), medium farms are more eco-efficient than large ones. It should be noted, that the DEA method was used in this case to measure eco-efficiency, and the criterion of the farms' size was the equivalent number of people employed at the farm on a full-time basis. Divergence in the results may arise from the slightly different production and economic characteristics of agriculture in the regions compared to Poland.

\section{Conclusions}

The discussion presented in the article brings us to the following conclusions:

1. Cross-analysis has shown that with the transition to groups of farms with an increasing economic size, the situation was more favourable from the perspective of accumulation rate and its level per 1 ha. The highest value was recorded in the ES5 group of farms. These tendencies result from broader opportunities for the optimisation of production factors and for achieving economies of scale.

2. In terms of the accumulation rate, the situation was unstable in the period under study and dependent on the economic conditions. However, in the analysed group, years with positive accumulation prevailed. Polarisation was observed in the case of the accumulation effort of farms. The smallest farms, i.e. the ES1-2 groups, diverged from the remaining farms to a growing extent. In the future, it may be expected that the significance of agricultural income in these farms will gradually decrease. However, this does not exclude the important role of these farms in maintaining the viability of rural areas. This function is already being indexed through payments for public goods, whose share in the subsidies was the highest in smaller farms.

3. Subsidies, without which the accumulation would be negative in all of the analysed groups of farms, substantially contribute to the shaping of the accumulation. The channel of accumulation associated with the increase in the prices of agricultural land was also important. This last factor limits the development processes in agriculture in terms of changes in the area structure.

\footnotetext{
Accumulation of assets in farms covered by the FADN farm accountancy system in Poland - the economic and eco-efficiency 
This means that in any case, the level of generated agricultural income was too low for the generation of accumulation.

4. It was observed that the higher rate of accumulation associated with the transition to groups of farms with greater economic strength is accompanied by an increase in eco-efficiency through the prism of the RTC ratio. Larger (but not the largest) farms are more efficient in using the transformation of environmental inputs into production output, which does not mean that they exert an absolutely lower environmental pressure. On the other hand, the importance of subsidies for public goods is lower in them, which indicates a less sustainable (in the environmental sense) nature of development.

In the light of the carried out studies, a recommendation could be formulated in order to take into account in the next budget outlook the diverse functions served by farms with different scales of production in the set of CAP instruments, including the issues concerning a more efficient use of environmental resources without causing degradation of the environment.

\section{Summary}

Accumulation of assets in farms covered by the FADN farm accountancy system in Poland - the economic and environmental context

The primary objective of the article is to identify the accumulation processes in farms in Poland based on the economic size as well as the context of eco-efficiency (from the perspective of Environmental Sustainable Value). In addition, the importance of subsidies in generating accumulation was specified and the context of ecoefficiency was taken into account. Analysis of the environmental context was carried out with the use of the assessment of subsidies for public goods and return to cost ratio (RTC) based on the concept of Sustainable Value (SV). Cross-analysis has shown that with the transition to groups of farms with an increasing economic size, the situation was more favourable from the perspective of the accumulation rate and its level per $1 \mathrm{ha}$. Subsidies play a significant role in shaping accumulation. It was observed that the higher rate of accumulation associated with the transition to groups of farms with greater economic strength is accompanied by an increase in eco-efficiency through the prism of the RTC indicator. Larger (but not the largest) farms are more efficient in using the transformation 
of environmental inputs into production output, which does not mean that they exert an absolutely lower environmental pressure.

Key words: accumulation, farm, subsidies, eco-efficiency, incomes.

\title{
Streszczenie
}

\begin{abstract}
Akumulacja majątku $w$ gospodarstwach rolnych objętych systemem rachunkowości rolnej FADN w Polsce - kontekst ekonomiczny i środowiskowy
\end{abstract}

Głównym celem artykułu jest rozpoznanie procesów akumulacji $w$ gospodarstwach rolnych $w$ Polsce ze względu na wielkość ekonomiczną jak również kontekst eko-efektywności (z perspektywy Environmental Sustainable Value). Do badania kontekstu środowiskowego wykorzystano ocenę dopłat za dobra publiczne oraz return to cost ratio (RTC), opierający się na koncepcji Sustainable Value (SV). Analiza przekrojowa wykazała, że wraz z przechodzeniem do grup gospodarstw o coraz większej wielkości ekonomicznej sytuacja była coraz korzystniejsza z perspektywy stopy akumulacji, jak i jej poziomu na 1 ha. Istotny udział w kształtowaniu akumulacji mają subsydia. Dostrzeżono, że wyższej stopie akumulacji związanej $\mathrm{z}$ przechodzeniem do grup gospodarstw rolnych o większej sile ekonomicznej, towarzyszy wzrost ecoefficiency przez pryzmat wskaźnika RTC. Gospodarstwa większe (ale nie największe) efektywniej wykorzystują transformację nakładów środowiskowych na efekty produkcyjne, co nie oznacza że wywierają absolutnie niższą presję środowiskową.

\section{Slowa}

kluczowe: akumulacja, gospodarstwo rolne, subsydia, ekoefektywność, dochody.

JEL

Classification: Q12, Q50, D25

\section{References}

1. Barham, B., Takasaki, Y., Coomes, O. (2000). Are endowments Fate? An Econometric Analysis of Multiple Asset Accumulation in a Biodiverse Environment. Conference Tokyo, Japan, December. http://www.gdnet. org/pdf/890_Yoshito.pdf. 
2. Behrman, J., Foster, A., Rosenzweig, M. (1995). Dynamic savings decisions in agricultural environments with incomplete markets. Journal of Business \& Economic Statistics, Vol. 15, No. 2, pp. 282-92. DOI: 10.1080/07350015.1997.10524706.

3. Bonfiglio, A., Arzeni, A., Bodini, A. (2017). Assessing eco-efficiency of arable farms in rural areas. Agricultural Systems, 151, pp. 114-125. DOI. org/10.1016/j.agsy.2016.11.008.

4. Burja, C., Burja, V. (2016). The Economic Farm Size And Sustainable Value Disparities Between Romania And The EU States. Annals of the Constantin Brâncuşi. University of Târgu Jiu, Economy Series, Issue 1.

5. 5. Ciaian, P., Kancs, D. (2012). The capitalization of area payments into farmland rents: micro evidence from the new EU member states. Canadian Journal of Agricultural Economics, Vol. 60, Issue. 4, pp. 517-540. DOI: 10.1111/j.1744-7976.2012.01256.x.

6. Czyżewski, B. (2017). Kierat rynkowy w europejskim rolnictwie (Market treadmill in European agriculture). Warszawa: PWN.

7. Czyżewski, B., Matuszczak, A., Muntean, A. (2018). Environmental sustainability in agriculture: different ways of quantification. In: Proceedings of the 2018 International Scientific Conference 'Economic Sciences for Agribusiness and Rural Economy'. Warsaw, pp. 40-47. DOI: 10.22630/ ESARE.2018.1.4

8. Figge, F., Hahn, T. (2004). Value-oriented impact assessment: the economics of a new approach to impact assessment. Journal of Environmental Planning and Management, 47 (6), 921-941. DOI.org/10.1080/0964056042000284901.

9. Figge, F., Hahn, T. (2005). The cost of sustainability capital and the creation of sustainable value by companies. Journal of Industrial Ecology, vol. 9, No. 4, pp. 47-58. https://doi.org/10.1162/108819805775247936.

10. Gadanakis, Y., Bennett, R., Park, J., Areal, F. (2015). Evaluating the Sustainable Intensification of arable farms. Journal of Environmental Management, 150. https:/ / doi.org/10.1016/j.jenvman.2014.10.005.

11. 11..Góral, J., Kulawik, J. (2015). Problem kapitalizacji subsydiów w rolnictwie. Zagadnienia Ekonomiki Rolnictwa, No. 1.DOI. 10.5604/00441600.1146845

12. Grzelak, A. (2014). Wybrane zagadnienia dotyczące akumulacji i reprodukcji majątku gospodarstw rolnych w Polsce w świetle wyników rachunkowości rolnej (FADN) (Selected issues regarding the accumulation and reproduction of farm assets in Poland in the light of the results of agricultural accounting system FADN). Przeglad Zachodniopomorski, No. 3, Vol. 2, pp. 305-314.

13. Illge, L., Hahn, T., Figge, F. (2008). Applying and Extending the Sustainable Value Method to Agriculture - an Overview. 12th Congress of the European Association of Agricultural Economists - EAAE, Ghent, Belgium. https://www.researchgate.net/publication/23510029_Applying_and_ 
Extending_the_Sustainable_Value_Method_related_to_Agriculture_-_ an_Overview.

14. Latruffe, L., Balcombe, K., Davidova, S., Zawalinska, K. (2004). Determinants of technical efficiency of crop and livestock farms in Poland. Applied Economics, 36(12), pp. 1255-1263. https:/ / doi.org/10.1080/0003684042000176793.

15. Liesen, A., Müller, F., Figge, F., Hahn, T. (2009). Sustainable Value Creation by Chemical Companies. Sustainable Value Research. Belfast. https:// www.sustainablevalue.com/downloads/sustainablevaluecreationbychemical companies .pdf).

16. Picazo-Tadeo, A., Gómez-Limón, J., Reig-Martínez, E. (2011). Assessing farming eco-efficiency: a data envelopment analysis approach. Journal of Environmental Management, 92(4), pp.1154-1164 DOI.org/10.1016/j. jenvman.2010.11.025.

17. Swinnen, J., Gow, H. (1999). Agricultural Credit Problems and Policies During the Transition to a Market Economy in Central and Eastern Europe. Food Policy Vol. 24, Issue 1. https:/ / doi.org/10.1016/S0306-9192(98)00067-0.

18. Swinnen, J., Vranken, L. (2009). Land \& EU Accession. Review of the Transitional Restrictions by New Members States on the Acquisition of Agricultural Real Estate. Centre for the European Policy Studies (CEPS), Brussels.

19. Winters, P., Benjamin, D., Gero, C., Covarrubias, K., Quinones, E., Zezza, A., Azzarri, C., Stamoulis, K. (2009). Assets, Activities and Rural Income Generation: Evidence from a Multicountry Analysis. World Development, Vol. 137, No. 9. https:/ / doi.org/10.1016/j.worlddev.2009.01.010.

20. Van Herck, K., Vranken, L. (2013). Direct payments and land rents: evidence from new member states. Factor Markets. Working Paper, No. 62, August. http:/ /dx.doi.org/10.2139/ssrn.2329931.

21. Van Passel, S., Nevens, F., Mathijs, E., Van Huylenbroeck, G. (2006). Explaining Differences in Farm Sustainability: Evidence from Flemish Dairy farms. International Association of Agricultural Economists Conference, Gold Coast, Australia, August 12-18. https://ageconsearch.umn.edu/ bitstream/25262/1/cp060302.pdf.

22. Van Passel, S., Nevens, F., Mathijs, E., Van Huylenbroeck, G. (2007). Measuring farm sustainability and explaining differences in sustainable efficiency. Ecological Economics, 62(1), pp.149-161. https://doi. org/10.1016/j.ecolecon.2006.06.008.

23. Zegar, J. (2003). Strategia polskiego rolnictwa po akcesji do UE (The strategy of Polish agriculture after accession to the EU). Zagadnienia Ekonomiki Rolnej, 3 (68). 